\title{
THE CONSOLE
}

\section{Something to remember.}

\section{BY ZACH CHAPMAN}

8 :45 p.m., Wednesday. Definitely too late to boot up the console. Rachel's supervisor had said she wouldn't get another warning. But she was out of beer and the flies buzzing over the dishes demanded to be ignored.

Rachel plugged in. The chime of the system eclipsed the rot inside her apartment.

The console reconstructed her memories, transporting her. November, six years ago.

Rachel approached her date. Vanessa stood at the corner of Sam's Burger Joint, shaking. She hadn't worn a jacket and the fishnets didn't warm her any. Her eyes alone had been a hard swipe right. Big and green and beautiful with winged eyeliner. And she still danced at Ska Thursdays.

Cramped inside the burger joint and under the spell of a deceased music genre, they slamdanced for two hours. After midnight, when the bands had packed up their trumpets, saxes, guitars and drums, Vanessa and Rachel shared a Guinness milkshake. When they hit the icy dregs, they kissed.

Vanessa coughed and held her chest, claiming it was from the cold shake. Even then, it was apparent, unless Rachel was rendering the memory wrong.

Rachel ripped out the plug. Disoriented, she banged her knee on her coffee table. The bowl of black fruit rocked. 2:45 a.m.

Rachel hadn't bothered with make-up, but she'd still been 40 minutes late.

The apartment's fire alarm went off. That's what she'd told her supervisor. Rachel had lost the guilt of lying, not that her supervisor believed her anyway.

One time. Rachel was told. One last chance. Don't let it happen again. Rachel ducked through the rest of the day.

She skipped dinner, went straight to the console.

Even on a cloudy day, Vanessa's eyes buzzed with light. The console got that right. Rachel looked down at their interlaced fingers. Vanessa's wrist glistened smooth, dark.

No. Not quite. Not perfectly Vanessa. Rachel strained to push the memory forward. Somewhere in that other world with the blackened fruit and angry management and Taco Bell bags, Rachel could hear

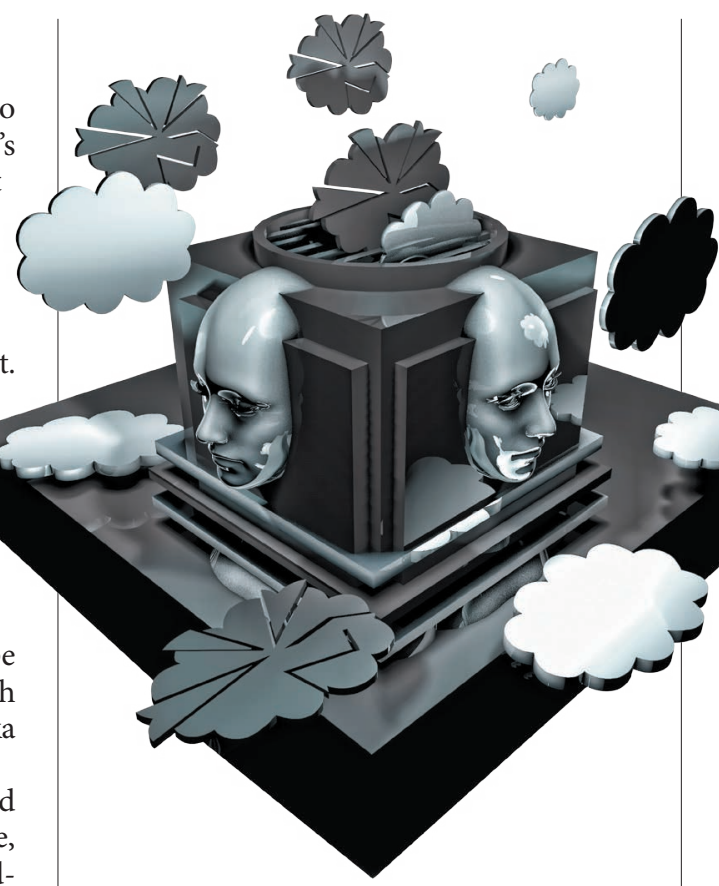

Rachel tried to suppress the memory. She knew it was getting close. The console buzzed, clicked, hissed but the recreated memory continued. Rachel spent the entire weekend trying to render it any other way,

but it always ended at the hospital.

By the time she arrived at work, it was 9:45 a.m., and her ska posters weren't pinned on her cubicle walls anymore. The vinyl pop figures were missing too. Company policy when letting someone go. They'd ship the stuff to her in a week or two. As she passed her supervisor on the way out, she just shrugged.

When Rachel got home, she watched the pulsing power button on the console. She needed to live. To breathe. To get out of the goddamn house. To be with Vanessa.

She booted the console.

Vanessa lay in a hospital bed. Her chest rose and fell slowly. At her side, Rachel read a book on her tablet, occasionally glancing at the medical monitor, trying to puzzle out its meaning. Her eyes were red, raw from crying.

A doctor would come in soon. Rachel wouldn't remember what he'd say. But she remembered what followed, those final days, the reiki and other useless treatments, the numbness, the funeral.

He doesn't have to come. It could play out differently. He doesn't have to...

The doctor opened the door to the small patient room and sat down next to Rachel. No! No!

"Your wife is going to be okay," he said. Rachel didn't understand. What was this? A new reality?

She caressed her wife's thin hair. Vanessa smiled up at Rachel. She still looked weak, but she was recovering. They'd be back to dancing and ice cream and pull-ups soon.

"You're perfect," Rachel said, letting the new idea solidify as her old memories faded. "We're going to go on so many adventures when you recover."

Zilker park. Rachel and Vanessa looked for a pole to do pull-ups on. Earlier, while holding hands in the back of a rickshaw, they had bet on who could do more. Rachel found a $\rightarrow$ NATURE.COM

Follow Futures: y @NatureFutures f go.nature.com/mtoodm next to a bike rack. Vanessa grabbed the branch, did one pullup and fell.
Somewhere in a different world, the console buzzed. -

Zach Chapman is an editor, author, gamer and sceptic. His fiction appears in numerous anthologies and podcasts. Like Robert E. Howard and Joe Lansdale, he's a Texan and loves writing pulp. 